\title{
I. ORGANIC-MATTER LEAN SEDIMENTS OF SITE 278, LEG 29, DSDP
}

\author{
Richard D. McIver, Esso Production Research Company, Houston, Texas
}

\section{INTRODUCTION}

As part of a continuing program of analyzing canned DSDP cores for gaseous hydrocarbons, 12 canned samples were studied from Site 278, Leg 29, DSDP. We anticipated moderate organic carbon and gas contents and thus elected to analyze the contents of all 12 samples.

As in previous cases, the samples were sealed very shortly after they were recovered on the deck of Glomar Challenger. They were shipped to this laboratory where organic carbon and hydrocarbon gases were determined by previously published procedures (McIver, 1973a).

\section{RESULTS AND DISCUSSION}

Results are tabulated in Table 1; and they are compared, graphically, with all the samples run previously (McIver, in press) in Figures 1 and 2. These samples were disappointingly lean in both organic carbon and hydrocarbon gas. Even the gas-to-organic-carbon index is very low, similar to the bathyl samples of Leg 21 (McIver, 1973b).

The gas contents are so low (trace to $135 \mathrm{ppmv}$ ), that they are the leanest suite of samples we have run for gas to date (McIver, in press). Even their organic carbon contents are in the range often found for deep-sea oozes away from the influence of land or upwelling currents (Hunt, in press).

They are even leaner in organic carbon than the previously leanest samples from Leg 21 . Thus, the
Miocene may be considered as a time when this site either received virtually no organic matter from the nearest land masses or overlying ocean or, the organic matter that was deposited was almost completely destroyed by oxidation, organisms, etc.

\section{ACKNOWLEDGMENTS}

The author is indebted to Ralph Pokluda and Harvey Fry who assisted with sample handling and analyses, and to Esso Production Research Company for continuing support to this work.

\section{REFERENCES}

Hunt, J. M., in press. Organic geochemistry of the marine environment. In Internatl. Congr. Organ. Geochem. 6th, Proc., Paris, France.

McIver, R. D., 1973a. Hydrocarbon gases from canned core samples, Sites 174A, 176, and 180. In Kulm, L. D., von Huene, R., et al., Initial Reports of the Deep Sea Drilling Project, Volume 18: Washington (U.S. Government Printing Office), p. 1013.

1973b. Low residual gas contents of four Leg 21 canned-sediment samples. In Burns, R. E., Andrews, J. E., et al., Initial Reports of the Deep Sea Drilling Project, Volume 21: Washington (U.S. Government Printing Office), p. 721 . , in press. Hydrocarbon gases in canned core samples from Leg 28, Sites 271, 272, and 273, Ross Sea. In Hayes, D. E., Frakes, L. A., et al., Initial Reports of the Deep Sea Drilling Project, Volume 28: Washington (U.S. Government Printing Office).

TABLE 1

Organic Carbon and Residual Gas Contents of Site 278 Samples

\begin{tabular}{lclcc}
\hline $\begin{array}{c}\text { Sample } \\
\text { Interval } \\
\text { in cm) }\end{array}$ & $\begin{array}{c}\text { Depth Below } \\
\text { Sea Floor } \\
(\mathrm{m})\end{array}$ & \multicolumn{1}{c}{ Age } & $\begin{array}{c}\text { Organic } \\
\text { Carbon } \\
(\%)\end{array}$ & $\begin{array}{c}\text { Hydrocarbon } \\
\text { Gas } \\
\text { (ppm by vol) }\end{array}$ \\
\hline $21-1,0$ & 281.5 & M to L Miocene & 0.07 & 135 \\
$21-3,0$ & 284.5 & M to L Miocene & 0.05 & $\operatorname{tr}^{\mathrm{a}}$ \\
$21-4,0$ & 286.0 & M to L Miocene & 0.05 & $\mathrm{tr}$ \\
$21-4,0$ & 286.5 & M to L Miocene & 0.08 & $\mathrm{tr}$ \\
$21-5,0$ & 287.5 & M to L Miocene & 0.05 & $\mathrm{tr}$ \\
$21-6,0$ & 289.0 & M to L Miocene & 0.05 & $\mathrm{tr}$ \\
$27-1,150$ & 338.7 & Early Miocene & 0.11 & $\mathrm{tr}$ \\
$27-2,0$ & 340.0 & Early Miocene & 0.10 & $\mathrm{tr}$ \\
$27-2,150$ & 340.2 & Early Miocene & 0.10 & $\mathrm{tr}$ \\
$27-3,0$ & 341.5 & Early Miocene & 0.11 & $\mathrm{tr}$ \\
$27-4,0$ & 343.0 & Early Miocene & 0.10 & $\mathrm{tr}$ \\
$27-5,0$ & 344.5 & Early Miocene & 0.11 & $\mathrm{tr}$ \\
\cline { 2 - 5 } & \multicolumn{5}{c}{}
\end{tabular}




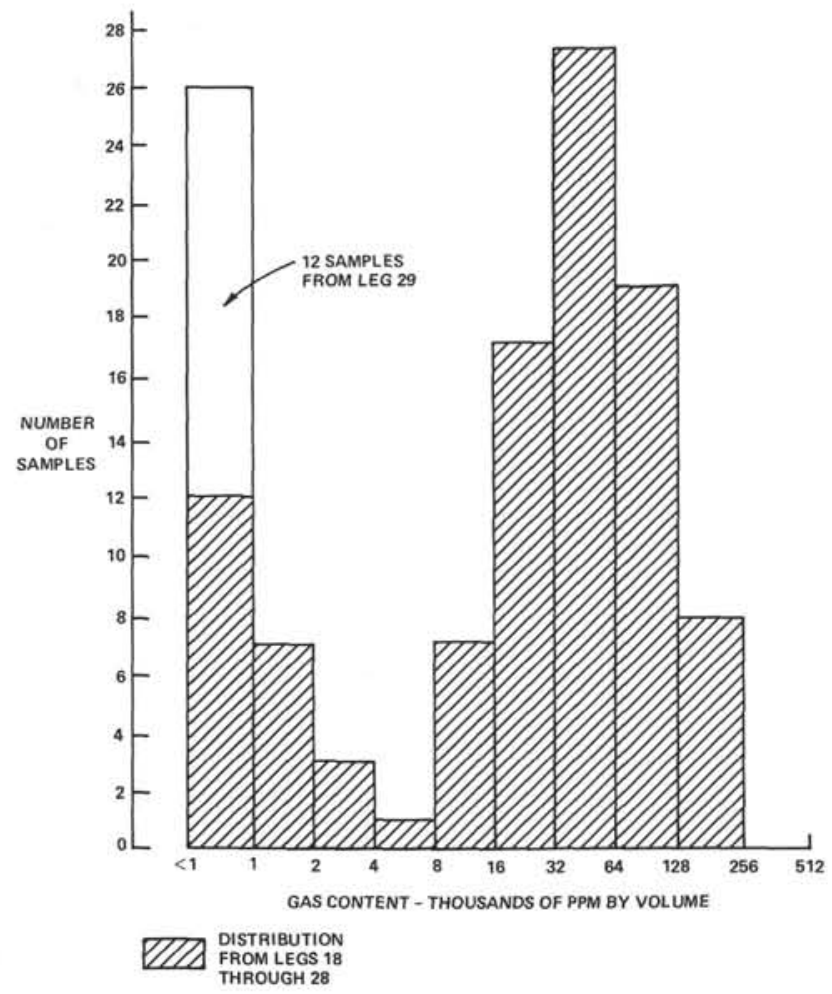

Figure 1. Residual hydrocarbon gas contents of Leg 29 samples compared with previous results (Legs 18-28, $D S D P$ ).

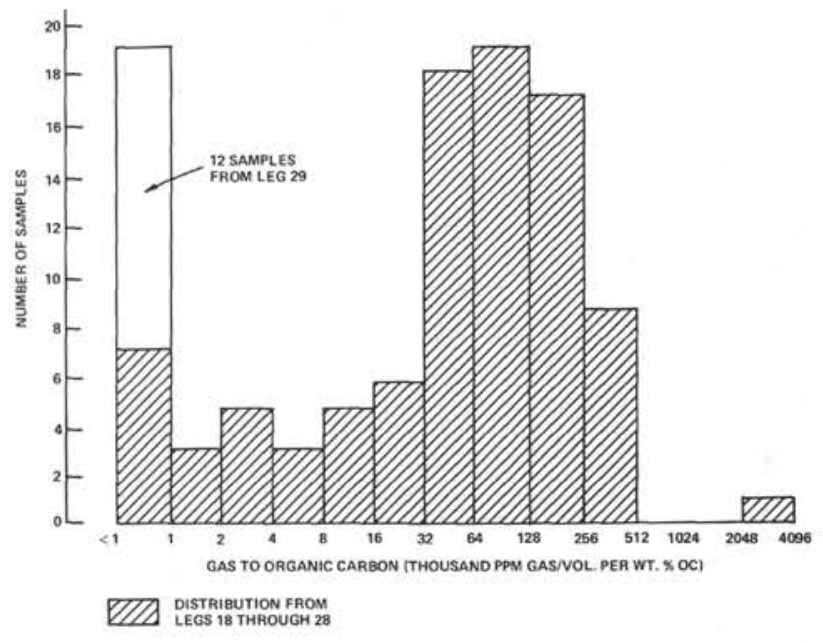

Figure 2. Hydrocarbon gas as a function of organic carbon contents - Leg 29 compared with previous results /Legs 18-28, DSDP). 